\title{
1. Introduction to Frontex, EASO and Europol as operational decentralized agencies
}

\section{SETTING THE SCENE}

\subsection{The Agencification of the Area of Freedom, Security and Justice}

Article 3(2) of the Treaty on the European Union (TEU) states that the European Union (EU) shall offer its citizens an Area of Freedom, Security and Justice (AFSJ). The AFSJ covers a wide range of policy fields: border management, asylum, migration, the recognition of judgments in civil and criminal matters, and police cooperation (Article 67 Treaty on the Functioning of the European Union (TFEU)). While these are very sensitive matters, representing traditional State-centered competences that are directly connected with national sovereignty and the fundamental rights of the individuals, the EU has a shared competence in AFSJ matters (Article 4(2)(j) TFEU). Additionally, the Member States shall adopt all measures of national law necessary to implement the Union acts (Article 291(1) TFEU in relation to Article 4(3) TEU).

The evolution of the AFSJ has been characterized by the Member States' reluctance to vest more powers in the EU institutions. However, events like the abolition of internal borders, the increasing migratory pressure at the European external borders, the rise in asylum applications or cross-border criminality could no longer be effectively managed by the national authorities individually. Therefore, one way to support the Member States and streamline their cooperation was through the establishment of several decentralized European agencies. These agencies' mission centers on providing assistance to the competent national authorities to ensure that the AFSJ policies are implemented. As the European Commission observes, "agencies have proved particularly relevant in field of shared competences, when the implementation of new policies at Community level needs to be accompanied by close 
cooperation between the Member States and the EU". ${ }^{1}$ EU decentralized agencies institutionally shape the AFSJ, deepen European integration to better tackle supranational and cross-border challenges and ensure the effective and uniform implementation of EU laws and policies at the national and local level.

Currently, the AFSJ has nine decentralized agencies, each with their own legal personality: European Agency for the Management of Operational Cooperation at the External Borders of the Member States of the European Union (Frontex), European Agency for the Operational Management of Large-Scale IT Systems in the AFSJ (EU-LISA), European Asylum Support Office (EASO), European Institute for Gender Equality (EIGE), European Monitoring Centre for Drugs and Drug Addiction (EMCDDA), European Police College (Cepol), European Police Office (Europol), EU Agency for Fundamental Rights (FRA) and the European Union's Agency for Judicial Cooperation (Eurojust). ${ }^{2}$ While Frontex, EASO, EU-LISA, and to a certain extent, Europol conduct their activities within the field of migration, border management and asylum, activities in the area of police and judicial cooperation are developed by Europol, Eurojust and Cepol (see Figure 1.1).

Additionally, the FRA, the EMCDDA and the EIGE contribute to the achievement of the AFSJ's objectives in a more tangential way. The FRA, the EMCDDA and the EIGE are information agencies in charge of gathering, analyzing and forwarding objective, reliable and comparable information; while Cepol and EU-LISA fit best under the management agencies category, which are mandated to provide services to other agencies and institutions. ${ }^{3}$ However,

1 Commission, European agencies - The way forward, $\operatorname{COM}(2008) 135$ final, 11.03.2008, p. 5.

2 Busuioc, Madalina and Curtin, Deirdre, "The EU internal security strategy, the EU policy cycle and the role of (AFSJ) agencies: promise, perils and pre-requisites", Study for the LIBE Committee, PE 453.185, 2011; Carrera, Sergio, et al., "The peculiar nature of EU Home Affairs agencies in migration control: Beyond accountability versus autonomy?", European Journal of Migration and Law, 15(4), 2013, pp. 337-358; Kaunert, Christian, et al., "Agency governance in the European Union's Area of Freedom, Security and Justice", Perspectives on European Politics and Society, 14(3), 2013, pp. 273-284; Parkin, Joanna, "EU Home Affairs agencies and the construction of EU internal security", CEPS Papers in Liberty and Security in Europe, 53, 2012, pp. 1-47; Pi Llorens, Montserrat, "El nuevo mapa de las agencias europeas del Espacio de Libertad, Seguridad y Justicia", Revista de Derecho Comunitario Europeo, 56, 2017, pp. 77-117; Santos Vara, Juan, "The EU's agencies: Ever more important for the governance of the Area of Freedom, Security and Justice" in Ripoll Servent, Ariadna and Trauner, Florian (eds), Routledge Handbook of Justice and Home Affairs Research, London: Routledge, 2018, pp. 445-455.

3 Commission, European agencies - The way forward, $\operatorname{COM}(2008) 135$ final, 11.03.2008, p. 7. The specialized literature regarding EU regulatory agencies has developed several functional classifications. See, among others, Chamon, Merijn, 
the operational nature of Frontex, EASO and Europol is a singularity that no other AFSJ agency has apart from Eurojust. ${ }^{4}$ That is, out of the nine agencies that operate in the AFSJ, only Frontex, EASO, Europol and Eurojust may use operational powers and may directly assist the competent national authorities on the ground in implementing the AFSJ goals (see Figure 1.1). ${ }^{5}$

The operational powers delegated to EU decentralized agencies may include facilitating the exchange of information between Member States to enable subsequent operational activities, training national competent authorities, coordinating and organizing joint operations, launching operations and conducting monitoring and inspection activities. ${ }^{6}$ The tasks conferred on Frontex, EASO and Europol fall into two categories: regulatory and operational. ${ }^{7}$ These agencies provide the Member States and the European Commission with technical and informational support to effectively achieve the AFSJ's goals. In addition, they operationally assist the competent national administrations via the coordination of joint operations or deploying support teams in the territory of the Member States. Hence, while Frontex, EASO and Europol develop classical regulatory competences bestowed upon many other EU decentralized agencies, the operational powers and work conducted on the ground clearly distinguish them and this is precisely the scope of analysis of this book.

"Transforming the EU Administration: Legal and Political Limits to Agencification", PhD thesis: Universiteit Gent, 2015, p. 32; Craig, Paul, EU Administrative Law, Oxford University Press, 2012, pp. 140-180; Geradin, Damien and Petit, Nicolas, "The development of agencies at EU and national levels: Conceptual analysis and proposals for reform", Jean Monnet Working Paper, 1, 2004, pp. 1-64; Vos, Ellen, "Agencies and the European Union" in Zwart, Tom and Verhey, Luc, Agencies in European and Comparative Law, Antwerp: Intersentia, 2003, p. 119.

4 Pi Llorens, Montserrat, "El nuevo mapa [...]", p. 85.

5 See Bigo, Didier, et al., "Mapping the field of the EU internal security agencies" in Bigo, Didier (ed.), The Field of the EU Internal Security Agencies, Centre d'études sur les conflits/l'Harmattan, 2007, pp. 5-66; Busuioc, Madalina, "European agencies and their boards: Promises and pitfalls of accountability beyond design", Journal of European Public Policy, 19(5), 2012, p. 39; Carrera, Sergio, et al., "The peculiar nature [...]", pp. 337-358; Kaunert, Christian, et al. (eds), Justice and Home Affairs Agencies in the European Union, London: Routledge, 2015; Rijpma, Jorrit, "Institutions and agencies: Government and governance after Lisbon" in Acosta Arcarazo, Diego and Murphy, Cian C. (eds), EU Security and Justice Law: After Lisbon and Stockholm, Oxford: Hart Publishing, 2014, pp. 54-76; Santos Vara, Juan, “The EU's Agencies [...]", pp. 445-455.

6 Chamon, Merijn, "Transforming the EU Administration”, p. 35.

7 Rijpma, Jorrit, "Hybrid agencification in the Area of Freedom, Security and Justice and its inherent tensions: The case of Frontex" in Busuioc, Madalina, et al., The Agency Phenomenon in the European Union: Emergence, Institutionalisation and Everyday Decision-Making, Manchester: Manchester University Press, 2012, p. 90. 


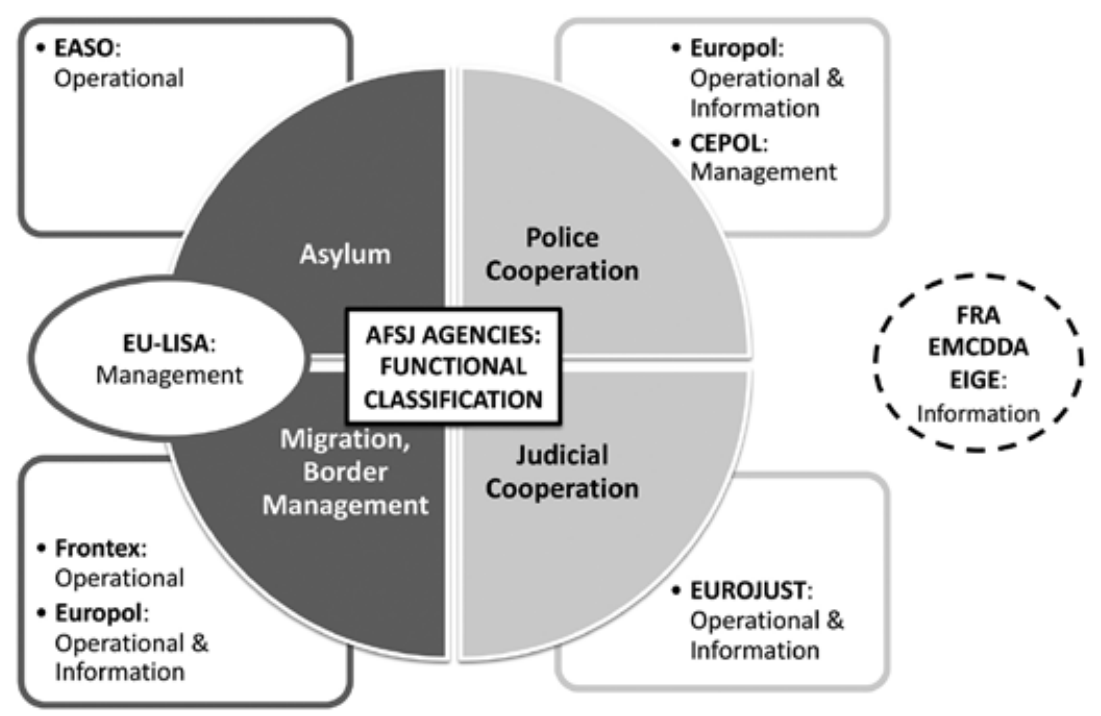

Source: Author's own elaboration.

Figure 1.1 Functional classification of the EU Area of Freedom, Security and Justice Agencies

Europol began operations in 1998 to facilitate the exchange of information and intelligence between the Member States. ${ }^{8}$ At that time, Europol was fully dependent on the willingness of the national authorities to provide them with valuable information. Only in recent years has Europol been assigned operational tasks to support the Member States in their illegal migrant smuggling investigations. Frontex was established in 2004 to improve the integrated management of the external borders, to render more effective the application of the EU measures relating to the management of external borders and to ensure the coordination of Member States' actions in the implementation of these measures. EASO was created in 2010 with the mission of strengthening practical cooperation among Member States on asylum matters, ensuring an effective implementation of the Common European Asylum System (CEAS)

8 See House of Lords (European Union Committee), "Europol's Role in Fighting Crime", 5th Report of Session 2002-03, 28.01.2003, p. 12. 
and providing operational support to Member States subject to particular pressure on their asylum and reception systems. ${ }^{9}$

Although Europol is explicitly mentioned in the Treaties, Frontex, EASO and Europol are set up through EU Regulations. ${ }^{10}$ Whereas Article 88 TFEU explicitly refers to Europol's mission and tasks, a similar legal basis regarding Frontex and EASO is missing from the Treaties. Due to the nonexistence of a general section in the Treaties to establish or confer competences on EU agencies, ${ }^{11}$ open clauses (namely, Articles 352 and 114 TFEU) and sectorial provisions became the legal bases for the introduction of EU decentralized agencies. Specifically, Frontex was created based on Articles 77(2)(b)(d) and 79(2)(c) TFEU and EASO was established according to Articles 74 and 78(1)(2) TFEU. These provisions confer on the European Parliament and the Council the power to adopt measures regarding the checks on persons crossing the European external borders, the gradual establishment of an integrated management system for external borders, the management of irregular migration including removal and repatriation and the development of a common policy on asylum, subsidiary protection and temporary protection.

Frontex and EASO have not been subdelegated implementing competences from the EU institutions, but rather, these agencies constitute specific institutional measures adopted with the aim of harmonizing the implementation tasks of the Member States. ${ }^{12}$ That is, Article 291(1) TFEU declares that Member States are primarily responsible for applying legally binding common acts in policy areas like border management, migration and asylum. However, the EU has been empowered to adopt measures in order to ensure a uniform and effective application of common AFSJ goals. Therefore, the key question to be answered is whether the term "measures", found in Articles 74, 77, 78 and 79(2)(c) TFEU, allows for the establishment of Frontex and EASO.

\footnotetext{
9 See Chapter 2.

10 Chamon, Merijn, "Transforming the EU Administration", p. 12.

11 According to Scholten, the absence of an explicit Treaty provision authorizing the creation and delegation of competences to the EU regulatory agencies has several implications that negatively impact the legitimacy of the agencies, their organization, management, creation and accountability. Scholten, Miroslava, The Political Accountability of EU and US Independent Regulatory Agencies, Leiden: Martinus Nijhoff Publishers, 2014, p. 63.

12 Hofmann, Herwig and Morini, Alessandro, "Constitutional aspects of the pluralisation of the EU Executive through 'agencification"', University of Luxembourg Law Working Paper Series, 1, 2012.
} 
The Court of Justice of the EU (CJEU) ruled in the cases Smoke Flavourings ${ }^{13}$ $E N I S A^{14}$ and Short-Selling ${ }^{15}$ that the concept, "measures for the approximation" of Article 114 TFEU, authorizes the establishment of EU regulatory agencies. ${ }^{16}$ Article 114(1) TFEU is an open clause that has served as a legal basis for the introduction of several agencies, since it grants the European Parliament and the Council the power to adopt measures for the approximation of national laws that have the establishment and functioning of the internal market as their object. Although the CJEU has not yet assessed whether the term "measures", found in Articles 74, 77, 78 and 79(2)(c) TFEU, authorizes the establishment of Frontex and EASO, the Court's reasoning, in regard to Article 114 TFEU, may be applied by analogy to Frontex and EASO.

Frontex and EASO constitute one of the "measures" that may be adopted to effectively and uniformly implement a common border management, migratory and asylum system at the EU level. Nevertheless, the operational powers conferred by the Member States upon the EU, in matters that do not fall within its exclusive competence, are governed by the subsidiarity and proportionality principles (Article 5 TEU) ${ }^{17}$ These principles respectively imply that Frontex, EASO and Europol may only act if and in so far as the Member States cannot sufficiently and effectively achieve their tasks and these AFSJ agencies' powers do not exceed what is necessary to achieve the objectives of the Treaties.

Regarding the subsidiarity principle, the European Commission's legislative proposals of Frontex, EASO and Europol specified that in light of the transnational nature of matters like border management, asylum or cross-border crime, national administrations are not qualified to individually develop a comprehensive and integrated policy. ${ }^{18}$ An EU agency is thus better

13 CJEU, "United Kingdom v Parliament and Council”, C-270/12, 22 January 2014, ECLI:EU:C:2014:18.

14 CJEU, "United Kingdom v Parliament and Council", C-217/04, 2 May 2006, ECLI:EU:C:2006:279.

15 CJEU, "European Parliament v Council of the European Union", C-363/14, 10 September 2015, ECLI:EU:C:2015:579.

${ }_{16}$ In this regard see Hofmann, Herwig, "Agencies in the European Regulatory Union", TARN Working Paper, 5, 2016, pp. 1-22.

17 For a detailed analysis of the limits to agencification flowing from the principles of subsidiarity and proportionality see Chamon, Merijn, "Transforming the EU Administration", pp. 217-238.

18 See Commission, Proposal for a Council Regulation establishing a European Agency for the Management of Operational Co-operation at the External Borders, $\operatorname{COM}(2003) 687$ final, 20.11.2003, p. 9; Commission, Proposal for a Regulation of the European Parliament and of the Council establishing a European Asylum Support Office, $\operatorname{COM}(2009) 66$ final, 18.02.2009, p. 4; Commission, Proposal for a Council 
positioned to enhance operational cooperation among the competent national authorities and reduce the differences and divergences between the applications of national legislation. ${ }^{19}$ Concerning the principle of proportionality, the European Commission indicates that the Regulations of Frontex, EASO and Europol are confined to the minimum required, and do not go beyond what is necessary to achieve their objectives. The Commission emphasizes that these agencies do not have any decision-making powers and do not replace the national administrations. ${ }^{20}$ That is, Frontex, EASO and Europol are established to assist the Member States in their implementation activities and further national action is not prevented.

\subsection{From a Secondary to a Key Operational Role of Frontex, EASO and Europol in the Aftermath of the 2015 "Refugee Crisis"}

While the early activities of Frontex, EASO and Europol centered on providing the competent national authorities with on-the-spot information, training or operational advice, these AFSJ agencies were progressively conferred with reinforced operational powers by directly assisting the Member States on the ground. Since 2007, Europol has been authorized to assist in every activity of the Joint Investigation Teams (JITs) and to participate in their establishment. ${ }^{21}$ That same year, Frontex's operational powers on the ground were significantly reinforced since the Agency could, upon request of a Member State, deploy Rapid Border Intervention Teams (RABITs). ${ }^{22}$ Subsequently, Regulation 1168/2011 introduced the European Border Guard Teams (EBGTs), which

Decision establishing the European Police Office (EUROPOL), COM(2006) 817 final, 20.12.2006, p. 7.

19 While the Commission insufficiently assessed the reasons and advantages of establishing Frontex and Europol as EU regulatory agencies, the EASO's Impact Assessment explored in greater detail why an agency was the most suitable institutional choice. Commission, Impact Assessment Accompanying the Proposal for a Regulation of the European Parliament and of the Council establishing an European Asylum Support Office, SEC(2009) 153, 18.02.2009, pp. 23-29. In this respect see Euréval, "Meta-Study on Decentralized Agencies: Cross-Cutting Analysis of Evaluation Findings", September 2008, pp. 26-30, 85-86; Ramboll, "Evaluation of the EU decentralised agencies in 2009", December 2009, pp. 11-17.

$20 \operatorname{COM}(2003) 687$ final, 20.11.2003, p. 9; $\operatorname{COM}(2009) 66$ final, 18.02.2009, p. 4; $\operatorname{COM}(2006) 817$ final, 20.12.2006, p. 7.

21 Council, Protocol amending the Convention on the establishment of a European Police Office (Europol Convention) and the Protocol on the privileges and immunities of Europol, the members of its organs, the deputy directors and the employees of Europol, OJ C-312, 16.12.2002.

${ }_{22}$ Regulation (EC) No 863/2007 of the European Parliament and of the Council of 11 July 2007 establishing a mechanism for the creation of Rapid Border Intervention 
could not only be deployed in the territory of a Member State facing an extraordinary and sudden arrival of irregular migrants, but also in every joint operation coordinated by Frontex. ${ }^{23}$ Regulation 439/2010 of EASO, following the model of Frontex's EBGTs, designed the Asylum Support Teams (ASTs). ${ }^{24}$ The ASTs can be deployed in the territory of a requesting Member State to provide emergency support to the national asylum and reception systems facing particular pressure. ${ }^{25}$

Nonetheless, the real thrust and reinforcement of the operational powers originally bestowed upon Frontex, EASO and Europol came in the aftermath of the so-called "refugee crisis". During 2015, the number of migrants who arrived at European shores grew exponentially. According to the United Nations High Commissioner for Refugees (UNHCR), while 216,054 migrants crossed the Mediterranean in 2014, 1,015,078 migrants travelled the same route in 2015 and 3,771 of them perished in the attempt. ${ }^{26}$ Over 90 percent of these migrants resorted to criminal networks, which illegally smuggled them into the Member States. ${ }^{27}$ In parallel, the number of asylum applications received by the frontline Member States in the course of 2015 amounted to $1,255,600$, doubling the number of applications registered in $2014 .^{28}$

As a result of the "refugee crisis" of unprecedented dimensions, the European Commission adopted on 13 May 2015 the European Agenda on Migration. ${ }^{29}$ The Agenda aimed to design a common strategy in which the Member States, the EU institutions, the AFSJ agencies, international organizations, civil society, local authorities and third countries were all involved in a coordinated

Teams and amending Council Regulation (EC) No 2007/2004 as regards that mechanism and regulating the tasks and powers of guest officers, OJ L-199, 31.07.2007.

23 Regulation (EU) No 1168/2011 of the European Parliament and of the Council of 25 October 2011 amending Council Regulation (EC) No 2007/2004 establishing a European Agency for the Management of Operational Cooperation at the External Borders of the Member States of the European Union, OJ L-304, 22.11.2011.

24 Regulation (EU) No 439/2010 of the European Parliament and of the Council of 19 May 2010 establishing a European Asylum Support Office, OJ L-132, 29.05.2010.

25 See Chapter 3.

26 UNHCR, "Refugees/Migrants Emergency Response - Mediterranean", http:// data.unhcr.org/mediterranean/regional.php.

27 Europol, "Migrant smuggling in the EU", February 2016, p. 13.

28 Eurostat, "Asylum in the EU Member States: Record number of over 1.2 million first time asylum seekers registered in 2015. Syrians, Afghans and Iraqis: top citizenships", 04.03.2016.

29 Commission, A European Agenda on Migration, $\operatorname{COM}(2015) 240$ final, 13.05.2015. See Carrera, Sergio, et al., "The EU's response to the refugee crisis: Taking stock and setting policy priorities”, CEPS Essay, 20, 2015, pp. 1-27. 
manner. ${ }^{30}$ The European Agenda on Migration aimed to shape an effective and balanced European migration policy with the aim of ensuring a coherent and effective response to the "refugee crisis". The purpose of the immediate actions tabled by the European Commission consisted in managing the exceptional influx of migrants crossing the Mediterranean. In this regard, the hotspot approach enhanced the operational assistance and inter-agency cooperation of Frontex, EASO and Europol in the territory of Member States subject to an exceptional and sudden migratory pressure. ${ }^{31}$ The European Agenda on Migration recommended addressing the structural limitations of the EU migration policy in the medium-term measures and signaled Frontex, Europol and EASO as key actors to promote operational cooperation and assistance on the ground. Specifically, the Agenda stated that the strategy should focus on (1) reducing incentives for irregular migration, (2) strengthening European external border management, (3) coherently implementing the CEAS, and (4) developing a new policy on legal migration. ${ }^{32}$ Lastly, completing the CEAS, designing a shared management of the European external border and introducing a new model of legal migration constituted the long-term objectives put forward by the European Agenda on Migration. ${ }^{33}$

In spite of the increased pressure that Frontex, EASO and Europol faced to offer further operational support to the Member States in uniformly and effectively applying the adopted EU instruments, the implementation deficit in the AFSJ was not overcome, but rather highlighted as a result of the "refugee crisis" from 2015 on.$^{34}$ Furthermore, the characteristic fragmentation of the AFSJ, resulting in overlaps and duplications among the several actors working in the AFSJ, also added to the existing implementation deficit. Neither the 2015 European Agenda on Migration, nor the AFSJ Strategic Agenda for the

30 See Carrera, Sergio, et al., "What priorities for the new European agenda on migration?", CEPS Commentary, 22 April 2015; Davitti, Daria and La Chimia, Annamaria, "A lesser evil? The European Agenda on Migration and the use of aid funding for migration control", UCD Working Papers in Law, Criminology \& Socio-Legal Studies, 7, 2017, pp. 1-46; Del Valle Gálvez, Alejandro, "Unión europea, crisis de refugiados, y 'limes imperii'", Revista General de Derecho Europeo, 38, 2016, pp. 1-13; Triandafyllidou, Anna and Mantanika, Regina, "Emergencia de refugiados en el Mediterráneo: evaluación de las respuestas políticas de la Unión Europea”, Migración y Desarrollo, 15(28), 2017, pp. 7-38.

$31 \operatorname{COM}(2015) 240$ final, 13.05 .2015 , p. 6.

$32 \quad$ Ibid., p. 6.

33 Ibid., p. 17.

34 European Migration Network, "A Descriptive Analysis of the Impacts of the Stockholm Programme 2010-2013”, May 2014, p. 6. 
2015-2020 period sufficiently addressed this issue. ${ }^{35}$ The former centered on adopting crisis management measures to ensure swift operational support to national authorities facing an extraordinary migratory pressure. The AFSJ Strategic Agenda for the 2015-2020 period vaguely stressed that the operational role of Frontex, EASO and Europol should be further developed, and that coherent transposition, effective implementation and consolidation are overall priorities for the AFSJ.

Specifically, regarding the role that the EU decentralized agencies should play in the AFSJ, the AFSJ Strategic Agenda for the 2015-2020 period stressed the importance of EASO to promote a full, uniform and effective implementation of the CEAS. ${ }^{36}$ The reactivity capabilities and operational support of Frontex to Member States subject to an exceptional migratory pressure at their external borders shall be strengthened. Additionally, the European Council mentioned that in the long term, the feasibility of designing a European system of border guards should be studied. ${ }^{37}$ Lastly, the AFSJ Strategic Agenda for the 2015-2020 period considered the coordination role of Europol essential to promote police operational cooperation, so as to prevent and combat cross-border crime. ${ }^{38}$

The "refugee crisis" revealed significant gaps in how the Member States applied EU laws and policies adopted in regard to migration, asylum and border management, hampering solidarity among the Member States. ${ }^{39}$ Precisely, the European Commission viewed the unprecedented "refugee crisis" in the EU as an opportunity to table ambitious reforms of the original Regulations of Frontex, EASO and Europol. Among the foremost measures put forward at the EU level to cope with this implementation deficit was the creation of the European Border and Coast Guard (EBCG) and the European Union Agency for Asylum (EUAA), the reinforcement of Europol's mandate and the promotion of their operational inter-agency cooperation on the ground through the hotspot approach. ${ }^{40}$ As stated by Busuioc, "in an area [the AFSJ] defined by strong national sovereignty concerns, policy development has been patchy and incremental, characterized by a preference for lighter instruments

35 European Council, "Extract from the 26-27 June 2014 European Council Conclusions concerning the area of Freedom, Security and Justice and some related horizontal issues", OJ C-240, 24.07.2014.

36 Ibid., para. 7.

37 Ibid., para. 9.

38 Ibid., para. 10.

39 Parliament, "Resolution on the situation in the Mediterranean and the need for a holistic EU approach to migration", 2015/2095(INI), 12.04.2016.

40 See Chapter 3. 
of governance punctuated by 'spasmodic' efforts at integration, often in response to and driven by crises". ${ }^{41}$

Consequently, in 2016 Europol's mandate was strengthened, ${ }^{42}$ Frontex was transformed into the $\mathrm{EBCG}^{43}$ and the European Commission tabled the creation of the EUAA. ${ }^{44}$ Although a partial agreement on the future EUAA has already been reached between the Council and the European Parliament, ${ }^{45}$ the Regulation repealing EASO has not yet been adopted. While the new legal frameworks of the EBCG and the EUAA formally repeal the Regulations establishing Frontex and EASO respectively, these two agencies have not disappeared, but have been renamed in order to emphasize the reinforcement of their operational functions. The EBCG and the future EUAA strictly build on the powers originally conferred respectively on Frontex and EASO. Since the EBCG continues to be referred to as Frontex and the Regulation of the EUAA has not yet been adopted, the terms "Frontex" and "EASO" are the ones generally used throughout this book unless the intention is to stress the operational novelties that their new legal mandates bring about.

The recently adopted mandates of Europol, the EBCG and the future EUAA aim to minimize the risk of future crises in the AFSJ and expand their operational support to the Member States. The new legal frameworks shift the reasoning of these agencies' powers and move from a reactive to a proactive

${ }^{41}$ Busuioc, Madalina, "EU Justice and Home Affairs agencies: Securing good governance", Study for the LIBE Committee, PE 596.812, 2017, p. 10. See Campesi, Giuseppe, "Crisis, migration and the consolidation of the EU border control regime", International Journal of Migration and Border Studies, 4(3), 2018, pp. 196-221; Goldner Lang, Iris, "The EU financial and migration crises: Two crises - many facets of EU solidarity" in Biondi, Alessandra, et al. (eds), Solidarity in EU Law: Legal Principle in the Making, Cheltenham, UK and Northampton, MA, USA: Edward Elgar Publishing, 2018; McDonough, Paul and Tsourdi, Evangelia, “The 'other' Greek crisis: Asylum and EU solidarity”, Refugee Survey Quarterly, 31(4), 2012, pp. 67-100; Scipioni, Marco, "Failing forward in EU migration policy? EU integration after the 2015 asylum and migration crisis", Journal of European Public Policy, 2017, pp. 1-19; Trauner, Florian, "Asylum policy: the EU's 'crises' and the looming policy regime failure", Journal of European Integration, 38(3), 2016, pp. 311-325.

42 Regulation (EU) No 2016/794 of the European Parliament and of the Council of 11 May 2016 on the European Union Agency for Law Enforcement Cooperation (Europol), OJ L-135, 24.05.2016.

43 Regulation (EU) No 2016/1624 of the European Parliament and of the Council of 14 September 2016 on the European Border and Coast Guard, OJ L-251, 16.09.2016.

44 Commission, Proposal for a Regulation of the European Parliament and of the Council on the European Union Agency for Asylum and repealing Regulation (EU) No 439/2010, $\operatorname{COM(2016)~} 271$ final, 04.05.2016.

45 Council, Proposal for a Regulation of the European Parliament and of the Council on the European Union Agency for Asylum and repealing Regulation (EU) No 439/2010 - State of play and guidance for further work, doc. 10555/17, 27.06.2017. 
approach. Their tasks will not only center on assisting the Member States and enhancing their coordination, but also preventing potential national vulnerabilities that may subsequently lead to an untenable scenario for the competent national authorities. The new Regulations of the EBCG, the EUAA and Europol aim to keep strengthening their autonomy from the Member States and to deepen their operational, monitoring and implementation role.

Europol designed the European Migrant Smuggling Centre (EMSC) to operationally assist the national competent authorities in their investigations. In addition, Europol is now authorized to launch and carry out investigations. In case a concerned Member State decides not to participate in such an investigation, it is required to provide Europol with a reasoned justification for its refusal within one month. The recently established EBCG and the future EUAA may require the competent national border and asylum authorities to effectively implement EU law and to take immediate action under emergency situations, and to this end, conduct vulnerability assessments or issue recommendations. The EBCG and the EUAA may even intervene in the territory of the Member States to ensure that the EU border management and asylum measures are applied and that the Schengen area and the CEAS are not ultimately jeopardized. Considering the EBCG's function to intervene directly on the ground was the main novelty brought about by Regulation 2016/1624, the introduction of a permanent body of border guards and the development of executive and coercive powers by the statutory staff of the Agency has made a comparable impact regarding Regulation 2019/1896 on the EBCG. ${ }^{46}$

Moreover, the European Agenda on Migration mandated Frontex, EASO and Europol to play a strengthened inter-agency operational role at the hotspots. ${ }^{47}$ While Frontex, EASO and Europol were already bilaterally and multilaterally cooperating before the hotspot approach was designed in 2015, their inter-agency interactions were essentially informal and flexible without binding them to concrete joint operational results. The "refugee crisis" revealed, however, the need to develop a more systematic multilateral cooperation between Frontex, EASO and Europol on the ground. The multilateral cooperation of Frontex, EASO and Europol has achieved an unprecedented degree of operationalization, coordination and systematization with the adoption of the "hotspot approach". ${ }^{48}$

46 Regulation (EU) 2019/1896 of the European Parliament and of the Council of 13 November 2019 on the European Border and Coast Guard and repealing Regulations (EU) No 1052/2013 and (EU) 2016/1624, OJ L-295, 14.11.2019.

47 See Chapter 4.

48 See Horii, Satoko, "Accountability, dependency, and EU agencies: The hotspot approach in the refugee crisis", Refugee Survey Quarterly, 2018, pp. 1-27. 
In the hotspots, Europol's guest officers are in charge of identifying risk profiles, performing second-line security checks and providing analytical and investigation support to dismantle illegal migrant smuggling networks. ${ }^{49}$ EASO assists the national asylum authorities by providing information to the arriving migrants, as well as identifying, registering and examining applications for international protection. The experts and technical equipment deployed by Frontex in the hotspots facilitate national sea border surveillance and search and rescue operations. Frontex also assists the national authorities in disembarking, screening, registering, identifying, fingerprinting, debriefing and assessing the nationality of the arriving migrants, as well as facilitating and coordinating the return operations of those migrants with no right to remain in the EU. ${ }^{50}$

In the hotspots, the Member States are no longer exclusively competent to register, identify, screen, debrief, inform or return arriving migrants, nor examine asylum applications. The competent national authorities, facing extraordinary migratory pressure at their external borders, further rely on Frontex, EASO and Europol. The hotspot approach is a flexible framework that allows these AFSJ agencies to tailor the degree of their operational assistance depending on the specific needs of the concerned Member States on the ground. The strengthened operational role and cooperation of these agencies is progressively moving the AFSJ towards an integrated migration, asylum and border protection administration.

\section{RESEARCH DESIGN}

The operational powers of Frontex, EASO and Europol are moving from technically assisting and supporting the Member States to developing tasks with an operational nature that have an impact in ensuring the effective and uniform implementation at the national level of the EU AFSJ laws and policies. The evolution of the operational tasks and cooperation of Frontex, EASO and Europol is analyzed in this book with the aim of assessing to what extent Frontex, EASO and Europol are playing a growing operational role in the AFSJ, as well as being increasingly involved in steering and shaping the implementation of EU border management, migration and asylum policies at the national and local level. Hence, this book centers on studying the reinforced legal mandate of Frontex, EASO and Europol to operationally support

49 Commission, EU Action Plan against migrant smuggling (2015-2020), $\operatorname{COM}(2015) 285$ final, 27.05.2015, p. 5 and A European Agenda on Migration, $\operatorname{COM}(2015) 240$ final, 13.05.2015, p. 3.

50 Explanatory note on the "Hotspot" approach, 15.07.2015, www.statewatch.org/ news/2015/jul/eu-com-hotsposts.pdf. 
the Member States, the operational tasks that these AFSJ agencies undertake in practice on the ground and whether a gap exists between the de jure and de facto operational tasks and cooperation.

Whereas the vague legal mandates of Frontex, EASO and Europol, which obscurely delimit their operational powers and inter-agency cooperation and the dearth of public information on the activities that these agencies conduct in practice, further complicate the analysis, the objective is to analyze the operational tasks that characterize Frontex, EASO and Europol among the rest of the EU regulatory agencies, and particularly, the specific scope of action and degree of intervention of these AFSJ agencies on the ground. This book thus delves into a new direction as to how EU decentralized agencies could be studied - in clusters per policy area with the aim of designing better and more effective policies. Analyzing the operational tasks and cooperation of Frontex, EASO and Europol moves away from the prevalent institutional analysis of EU decentralized agencies, to a policy-driven analysis of these EU decentralized agencies in order to assess their added value and complementarity in achieving the objectives of the AFSJ and addressing the particular challenges afflicting this policy area. ${ }^{51}$

However, Frontex, EASO and Europol's scope of action is not limited to operationally assisting Member States. Frontex has also been conferred with capacity building tasks designed to assist Member States in training national border guards, creating common training standards, carrying out risk analysis, developing research for the management of external borders and providing a constantly updated picture of the EU's external borders and migration situation. ${ }^{52}$ Apart from the special and emergency operational support and the deployment of ASTs on the ground by EASO, the Agency also conducts training, quality, information and analysis activities..$^{53}$ Europol is not an agency whose activities merely center on migration and asylum matters. In comparison to Frontex and EASO, Europol plays a secondary role in border management, migration and asylum matters. Europol is also responsible for assisting two or more Member States in fighting serious and organized forms of crime by providing law enforcement expertise, developing information on criminal activities and facilitating law enforcement operations. ${ }^{54}$

51 See Lalikova, Laura and Scholten, Miroslava, “EU Agencies' label: To what extent should we treat them all as 'one'?', RENFORCE Blog, 17.10.2017, http://blog .renforce.eu/index.php/en/2017/10/17/eu-agencies-label-to-what-extent-should-we -treat-them-all-as-one-2/.

52 See Article 10 Regulation 2019/1896.

53 See Article 2 Regulation 439/2010.

54 See Article 4 Regulation 2016/794. 
Whereas the mandate and mission of Frontex, EASO and Europol are broader, this book only focuses on these agencies' operational role when supporting the Member States in border management, asylum and illegal migrant smuggling matters, respectively. The non-operational tasks of Frontex, EASO and Europol are not the subject matter of this book, which exclusively centers on analyzing: (1) the operational support that Frontex, EASO and Europol provide to a concerned EU Member State, excluding any operational tasks bestowed upon these agencies that is not addressed to a Member State; (2) the operational cooperation between Frontex, EASO and Europol, excluding any bilateral and multilateral exchange of information between these agencies and any operational cooperation between these agencies and the EU institutions or third countries. In this regard, how the operational activities and cooperation of Frontex, EASO and Europol are monitored, to what extent these agencies are held accountable, and the allocation of responsibilities between the actors involved in their operations are not the subject matter of this book either. Nevertheless, by examining the de jure and de facto operational tasks of Frontex, EASO and Europol, this book may indirectly shed light on the distribution of responsibilities or better monitoring of these agencies' reinforced operational activities and cooperation.

\section{SCIENTIFIC RELEVANCE}

This book explores the exponential agencification of the AFSJ, the distinctive characteristics of three EU decentralized agencies that operate within the AFSJ, the noteworthy expansion of the operational tasks and cooperation of Frontex, EASO and Europol, and the crucial role that these agencies are called to play in ensuring an effective and uniform implementation of the common border management, migration and asylum laws and policies. Nonetheless, agencification has not been a process confined solely to the AFSJ, but rather developed in parallel to the European integration process, which requires a harmonized implementation of the EU laws and policies. As stressed by the European Commission, "the creation of further autonomous EU regulatory agencies in clearly defined areas will improve the way rules are applied and enforced across the Union". ${ }^{55}$ The added value of the EU agencies as an institutional and administrative governance option underpinned to a great extent their exponential creation and empowerment. ${ }^{56}$ Credibility, efficiency and crisis

55 Commission, European Governance: A White Paper, $\operatorname{COM}(2001) 428$ final, 25.07.2001, p. 24.

56 See Commission, Analytical Fiche $\mathrm{Nr}$ 2, "Creation of Agencies", 2010; Commission, Meta-Evaluation on the Community Agency System, 15.09.2003, pp. 28-31. 
management are widely acknowledged by the literature as key reasons for the establishment of EU agencies. ${ }^{57}$

The progressive extension of EU powers into greater policy fields required the European Commission to shift its attention from policymaking to administrative, technical and implementation tasks. Without the assistance of the EU decentralized agencies, the Commission was at risk of becoming an inflexible institutional mastodon. Decentralized agencies became the preferred institutional option to improve the credibility, accountability, legitimacy, transparency and visibility of EU governance, and to effectively and consistently apply growing common policies and laws. Despite the significant role of the decentralized agencies in the EU, they were established on an ad hoc basis. That is, a common definition, binding framework and classification of the EU decentralized agencies regulating their accountability, management and functioning are missing.

As a result, the agencification phenomenon in the EU has received profound scholarly attention. ${ }^{58}$ Academics are interested in the rationale behind the agencies' establishment, ${ }^{59}$ the balance between their independence and accountability, ${ }^{60}$ their constitutionality, their legal bases and the control of

57 For a more detailed literature review of the advantages of delegating powers to EU agencies see Mathieu, Emmanuelle, Regulatory Delegation in the European Union: Networks, Committees and Agencies, London: Palgrave Macmillan, 2016, pp. 2-15.

58 See in particular "The Academic Research Network on Agencification of EU Executive Governance" (TARN) project, https://tarn.maastrichtuniversity.nl.

59 Christensen, Jorgen and Nielsen, Vibeke, "Administrative capacity, structural choice and the creation of EU agencies", Journal of European Public Policy, 17(2), 2010, pp. 176-204; Curtin, Deirdre, Executive Power of the European Union. Law, Practices and the Living Constitution, Oxford: Oxford University Press, 2009; Fuentetaja Pastor, Jesús Ángel, "Las Agencias Ejecutivas de la Comisión Europea", Revista de Derecho de la Unión Europea, 6, 2004, pp. 123-159; Geradin, Damien, "The development of European regulatory agencies: What the EU should learn from American experience", Columbia Journal of European Law, 11, 2004, pp. 1-52; Thatcher, Mark, "The creation of European regulatory agencies and its limits: A comparative analysis of European delegation", Journal of European Public Policy, 18(6), 2011, pp. 790-809; Vírgala Foruria, Eduardo, Las Agencias Reguladoras de la UE, Granada: Comares, 2011.

60 Busuioc, Madalina, European Agencies; Curtin, Deirdre, "Holding (quasi-) autonomous EU administrative actors to public account", European Law Journal, 13(4), 2007, pp. 523-541; Everson, Michelle, "Independent agencies: Hierarchy beaters?", European Law Journal, 1(2), 1995, pp. 180-204; Everson, Michelle, et al. (eds), European Agencies in between Institutions and Member States, Alphen aan den Rijn: Kluwer Law International, 2014; Groenleer, Martijn, "The Autonomy of European Union Agencies: A Comparative Study of Institutional Development", PhD thesis: Technical University of Delft, 2009; Majone, Giandomenico, "The rise of the regulatory State in Europe", West European Politics, 17(3), 1994, pp. 77-101; Saurer, 
their ever-growing tasks in each EU policy. ${ }^{61}$ In particular, it has recently been noticed that the powers bestowed upon the EU decentralized agencies are not only expanding, but are also increasingly involved in making political, economic or social choices, which their mandates vaguely and openly regulate. ${ }^{62}$ Although Frontex, EASO and Europol have also been subject to analysis, the literature has centered on studying those EU decentralized agencies involved in the application of laws and policies relating to the single market. ${ }^{63}$ Within the AFSJ, the scholarly attention regarding EU decentralized agencies has predominantly focused on studying separately Frontex and Europol, their establishment, their competences, their accountability, their impact on the fundamental rights of individuals or the demarcation of responsibilities between the agencies and the Member States.

The evolution of the operational tasks of Frontex, EASO and Europol, their reinforced inter-agency cooperation on the ground, the expansion of their operational mandate to the frontline Member States in the aftermath of the 2015 "refugee crisis" and their increasing role in ensuring an effective and harmonized national implementation of border management, migration and asylum measures adopted at the EU level is under-researched. A knowledge gap exists between the operational functions de jure conferred on Frontex, EASO and Europol and the activities that these agencies increasingly conduct de facto on the ground.

Johannes, "The accountability of supernational administration: The case of European Union agencies", American University International Law Review, 24(3), 2008, pp. 429-488; Simoncini, Marta, Administrative Regulation beyond the Non-Delegation Doctrine: A Study on EU Agencies, Oxford: Bloomsbury Publishing, 2018.

${ }_{61}$ Busuioc, Madalina, et al. (eds), The Agency Phenomenon in the European Union, Manchester, Manchester University Press, 2012; Chamon, Merijn, EU Agencies: Legal and Political Limits to the Transformation of the EU Administration, Oxford: Oxford University Press, 2016; Chiti, Edoardo, "An important part of the EU's institutional machinery: features, problems and Perspectives of European agencies", Common Market Law Review, 46(5), 2009, pp. 1395-1442; Dehousse, Renaud, "Regulation by networks in the European Community: The role of European agencies", Journal of European Public Policy, 4(2), 1997, pp. 246-261; Geradin, Damien, et al. (eds), Regulation through Agencies in the EU: A New Paradigm of European Governance, Cheltenham, UK and Northampton, MA, USA: Edward Elgar Publishing, 2005.

${ }_{62}$ Schammo, Pierre, "The European Securities and Markets Authority: Lifting the veil on the allocation of powers", Common Market Law Review, 48, 2011, pp. 1879-1887; Scholten, Miroslava and Van Rijsbergen, Marloes, "Limits of agencification in the European Union", German Law Journal, 15(7), 2014, pp. 1223-1256; Van Cleynenbreugel, Pieter, "Meroni circumvented? Article 114 TFEU and EU regulatory agencies", Maastricht Journal of European and Comparative Law, 21, 2014, pp. 64-88; Vos, Ellen, "EU agencies on the move: Challenges ahead", Swedish Institute for European Policy Studies, 1, 2018.

${ }^{63}$ Kaunert, Christian, et al., “Agency governance [...]”, p. 275. 
While the operational tasks of Frontex, and to a lesser extent EASO and Europol, have been separately studied by the literature, a comparative analysis on the operational powers and cooperation of Frontex, EASO and Europol is necessary. The expansion of the operational activities and multilateral cooperation of these agencies on the ground to the frontline Member States is unprecedented. It is timely to comparatively analyze the evolution of the operational powers of Frontex, EASO and Europol in border management, asylum and migration matters and to examine to what extent the tasks that they conduct in practice are aligned with the provisions established in their recently adopted or proposed Regulations. Research is needed in regard to the degree of operational support that Frontex, EASO and Europol are providing and the impact of these agencies' activities in shaping the implementation of a further integrated administration of the AFSJ.

This book also contributes to the current scholarly research regarding the increasing involvement of the EU in the implementation or enforcement of laws and policies. ${ }^{64}$ It is argued that the focus of the EU in border management, migration and asylum matters is shifting from adopting measures to tackling the existing implementation deficit. The analysis of the evolution of the operational tasks of Frontex, EASO and Europol contributes to the understanding as to what extent the assistance of these agencies has an impact on the implementation prerogatives of the Member States. Currently, there are three priorities in the AFSJ: to offer operational support to the Member States, to promote cooperation and coordination and to ensure a uniform and effective implementation of the AFSJ policies and instruments adopted at the EU level.

64 Among many, see Groenleer, Martijn, et al., "Regulatory governance through agencies of the European Union? The role of the European agencies for maritime and aviation safety in the implementation of European transport legislation", Journal of European Public Policy, 17(8), 2010, pp. 1212-1230; Luchtman, Michiel and Vervaele, John, "European agencies for criminal justice and shared enforcement (Eurojust and the European Public Prosecutor's Office)", Utrecht Law Review, 10(5), 2014, pp. 132-150; Ottow, Annetje, "Europeanization of the supervision of competitive markets", European Public Law, 18(1), 2012, pp. 191-221; Scholten, Miroslava, "Mind the trend! Enforcement of EU law has been moving to "Brussels", Journal of European Public Policy, 24(9), 2017, pp. 1348-1366; Scholten, Miroslava and Luchtman, Michiel (eds), Law Enforcement by EU Authorities, Cheltenham, UK and Northampton, MA, USA: Edward Elgar, 2017; Treib, Oliver, "Implementing and complying with EU governance outputs", Living Reviews in European Governance, 1(1), 2006, pp. 1-26; Versluis, Esther, "Even rules, uneven practices: Opening the 'black box' of EU law in action", West European Politics, 30(1), 2007, pp. 50-67. See also "The Jean Monnet Network on EU Law Enforcement", EULEN project, https://jmn-eulen.nl and the Utrecht Centre for Regulation and Enforcement in Europe (RENFORCE), www.uu.nl/en/research/utrecht-centre-for-regulation-and-enforcement -in-europe. 
Due to the predominantly operational nature of the AFSJ, the EU decentralized agencies stand out as the mode of administrative governance, specially tasked with providing technical expertise, exchanging information and coordinating the operational activities of the Member States. Consequently, attention is gradually shifting from adopting new AFSJ policy proposals and laws to effectively and evenly implementing the existing policy and legislative instruments at the national level. EU AFSJ agencies were called to play a key operational role in the implementation of the EU policies on migration, asylum, border management and police and judicial cooperation in criminal matters. Precisely, in relation to EU migration, asylum and external border management policies, the Stockholm Programme underlined that "effective implementation of all relevant legal instruments needs to be undertaken and full use should be made of relevant Agencies and Offices operating in this field" ${ }^{65} \mathrm{In}$ the same vein, the 2014 European Council conclusions, setting the strategic guidelines until 2020 for the AFSJ, stressed that implementation should be the overall priority. The operational functions of agencies like Frontex, EASO and Europol should be further developed to contribute to "filling the gap between political decisions in Brussels and the reality on the ground". ${ }^{66}$

\section{OUTLINE OF THE BOOK}

This book is divided into six chapters. The first and last chapters are devoted to the introduction and the conclusion. The second chapter studies the establishment and initial operational tasks of Frontex, EASO and Europol, which directly influence the current operational powers and cooperation bestowed upon these AFSJ agencies. In particular, the agencification of the AFSJ, the increasing delegation of operational tasks to Frontex, EASO and Europol and the progressive Europeanization of the Justice and Home Affairs (JHA) matters are examined. Frontex, EASO and Europol reflect, as the "refugee crisis" has clearly revealed, the institutional tug-of-war between the Member States and the EU in very sensitive matters such as border management, asylum and migration.

Chapter 3 maps Frontex, EASO and Europol's growing operational tasks and the impact of their activities on the ground as EU decentralized agencies. Specifically, the deployment of EBGTs by Frontex and of ASTs by EASO, and the participation of Europol in JITs, is examined. Furthermore, the oper-

65 European Council, The Stockholm Programme - An Open and Secure Europe Serving and Protecting Citizens, OJ C-115, 04.05.2010, p. 5.

${ }_{66}$ Mid-term review of the JHA strategic guidelines - Information from the Presidency, doc. 15224/17, 01.12.2017, p. 10. 
ational novelties of the recently adopted Regulation 2016/794 of Europol, Regulation 2016/1624 and Regulation 2019/1896, which transform Frontex into the EBCG, and the proposed Regulation on the EUAA, repealing EASO, are explored. Special attention is paid to the increasing operational role of Europol, the autonomy and overseeing tasks of the EBCG and the future EUAA, as well as their role in shaping and steering a uniform and effective implementation. The degree of discretion that Frontex, EASO and Europol enjoy in operationally supporting the competent national authorities to effectively and uniformly implement the AFSJ objectives is explored.

Chapter 4 centers on studying the operational cooperation between Frontex, EASO and Europol. In particular, this chapter firstly describes the concept and implications of operational cooperation, as well as the terms, "duplication", "overlap" and "fragmentation". Secondly, the bilateral and multilateral operational cooperation between Frontex, EASO and Europol is explored. Thirdly, the hotspot approach, established in 2015 by the European Agenda on Migration, is examined. In particular, the functioning and the operational tasks of Frontex, EASO and Europol in the hotspots are scrutinized. Lastly, the limitations and impact of the reinforced multilateral inter-agency cooperation between Frontex, EASO and Europol in the hotspots is studied. Special attention is paid to the activities that these agencies carry out in practice at the hotspots, so as to ensure an effective and harmonized implementation of the migration, border management and asylum policies.

Chapter 5 centers on examining the limitations to the reinforced operational tasks and cooperation of Frontex, EASO and Europol. This chapter firstly explores, in light of the principal-agent theory, the concept of delegation of powers and the inadequacy of this model in regard to Frontex, EASO and Europol. Subsequently, the evolution of the CJEU's non-delegation doctrine, from Meroni and Romano to Short-Selling, and its impact on the conferral of powers on EU agencies is analyzed. In particular, the implications of the CJEU's non-delegation doctrine to Frontex, EASO and Europol in the post-Lisbon era are assessed, and the degree of discretion that these bodies may enjoy in effectively and uniformly implementing the adopted AFSJ measures is examined. This chapter concludes by studying the internal governance and administrative structures of Frontex, EASO and Europol and the influence that the Member States and civil society exert through the management boards, the executive directors, the consultative forums, the fundamental rights officers and the complaints mechanisms of the agencies. 